\title{
Is daily intake of pesticide residues in foods acceptable?
}

\author{
A ingestão diária de resíduos de agrotóxicos em \\ alimentos é aceitável?
}

\author{
¿Es aceptable la ingestión diaria de residuos \\ procedentes de pesticidas en alimentos?
}

\author{
Carla Vanessa Alves Lopes 1 \\ Guilherme Souza Cavalcanti de Albuquerque 1
}

doi: 10.1590/0102-311X00096621

An article we wrote entitled Challenges and Strides in the Control of Pesticide Residues in Brazil: 15 Years of the Program for Analysis of Pesticide Residues in Food Products ${ }^{1}$ prompted a letter from Paumgartten 2, pointing to the need for some clarifications.

Paumgartten 2 (p. 1) begins by stating that "evidence-based risk management of pesticides is a complex multistep process that integrates Science, uncertainties and social values to guide regulatory decision-making", on which we agree. We further affirm that when taking a stance on social values, we take the side of those who defend life and health over all else, including commercial interests.

As for the concepts of maximum residue limits (MRL) and acceptable daily intake (ADI), we agree that it is the relative contribution of each food item within a basic dietary basket, with its pesticide residue, that determines whether exposure exceeds or falls within the ADI. Precisely for this reason, the crucial and most worrisome point revealed by the article is that during the 15 years of the Brazilian Program for Analysis of Pesticide Residues in Food Products (PARA), it was not "occasional" violations of MRL that occurred, but the persistence of this irregularity in various foods analyzed, and worse still, the presence of several unauthorized active ingredients in specific crops. These results certainly highlight flaws in good agricultural practices, but one cannot take for granted, or much less fail to recognize, that this irregularity results in greater intake of pesticides in Brazilians' diet.

In the article, citing Carneiro et. al. 3, we state, "The two types of calculations applied to the object of study of toxicology are part of a rhetoric of misrepresentation that is only useful for transmitting the idea of trust in so-called tolerance limits".

An article by Vasconcelos 4 entitled A Critical View of the Use of Exposure Standards in Occupational Health Surveillance already showed, backed extensively by the literature, that historically, the establishment of tolerance limits, acceptable exposure levels, permissible exposure levels, limits of exposure, and maximum acceptable concentrations suffer deviations and omissions and are subject to political and economic interference that overrides health interests. Based on work by Holmberg \& Winel 5 , Vasconcelos questions the idea that there is a determined risk level for exposure to chemical products where it is possible to identify a zero-effect point for each substance or factor. The latter authors demonstrated that the values differ in each country depending on the correlation of forces of the various actors involved in their definition and the criteria used to establish them. Holmberg \& Winel further
1 Universidade Federal do Paraná, Curitiba, Brasil.

Correspondence

C. V. A. Lopes Universidade Federal do Paraná.

Rua Padre Camargo 280, Curitiba, PR 80060-240, Brasil. carla.valopes.ufpr@gmail.com 
showed that for the "standards" used in organic solvents, the values set in the United States were up to 95 times higher than those adopted in the Soviet Union.

Vasconcelos 4 also cites a study by Castleman \& Ziem 6 demonstrating that in most of the cases studied, the standards were based on scanty scientific evidence, sometimes without even a minimal literature review. Castleman \& Ziem reported that committee members responsible for setting the standards were simultaneously consultants to industrial conglomerates with vested interests; that corporate influence in setting the values frequently drew on unpublished data and even personal experience reported by telephone; that it was obvious that the companies' interference was for economic reasons and because they had more experience with the product; and that the committee on threshold limit values (TLV) failed to provide other social sectors with the same opportunity for participation. They concluded that it was crucial for parties with vested financial interests not to oversee the process of setting standards.

These studies are not recent, nor is the study by Ito 7, cited by Paumgartten, but merely illustrate the history of defining purportedly safe parameters, a situation that unfortunately persists to this day.

The book Our Daily Poison: From Pesticides to Packaging, How Chemicals Have Contaminated the Food Chain and Are Making Us Sick 8 shows that such interference persists, and that even today, regulatory agencies base their decisions on the weak studies submitted by industry itself, interested in marketing its products. This produces such distortions as the authorization of products whose harmful effects (which would contraindicate their use) have already been extensively documented, or the establishment of ADIs many times higher than the intake levels that cause severe harm, as shown in animal studies. So-called "independent experts" calculate the dose based on a summary of the studies performed by industry companies, whose data are kept an industrial secret, thus serving commercial interests rather than the public health. The expert committees and regulatory agencies are thus forced to rely on corporate studies. The differences between the limits tolerated in Brazil versus the European Union can reach 5,000-fold in the case of pesticide residues in water ${ }^{9}$, clearly demonstrating the parameters' lack of safety. Obviously, there is no scientific evidence whatsoever that Brazilians are more resistant than Europeans to exposure to poisons.

The dose-effect principle may function for some conventional products, but it is completely erroneous for others. Various currently used chemical products act as hormones, for which the dose does not determine the poison. Infimal doses can trigger an effect, while high doses may inhibit it 10.

Equally disturbing is the fact that the no-observed-adverse-effect-level (NOAEL) used to calculate the ADI for humans is based on a safety factor obtained by dividing by 100 the lowest-observedadverse-effect-level (LOAEL). This "safety factor" is totally arbitrary and has no epidemiological basis.

Studies of toxic cocktails have clearly demonstrated their synergic effect, for example in research by the laboratory of the University of Copenhagen (Denmark) 11. The article by Ito et al. 7, cited by Paumgartten to refute the synergy between various poisons, displays at least one evident methodological flaw. Its conclusions are based on a study that monitors the development of neoplasms in rats for only eight weeks. In adulthood, each month of a rat's life corresponds to only 2.5 years in humans 12 . As demonstrated by Séralini et al. 13, observation of the emergence of chronic diseases in rats requires long-term follow-up, preferably throughout the animal's life, which is approximately three years.

Chemical products' synergism is thus evidenced by studies from agronomy itself, acknowledging the enhancement of pesticides' effects when associated with the extermination of organisms that the farmer considers undesirable.

The question raised here has provoked both researchers and readers in general. We feel that it merits more space for proper understanding, since it was not the primary focus of the article to delve into this debate in greater depth. 


\section{Contributors}

Both authors contributed to writing and revising the text.

\section{Additional informations}

ORCID: Carla Vanessa Alves Lopes (0000-00027157-4285); Guilherme Souza Cavalcanti de Albuquerque (0000-0002-7544-412X).
1. Lopes CVA, Albuquerque GSC. Desafios e avanços no controle de resíduos de agrotóxicos no Brasil: 15 anos do Programa de Análise de Resíduos de Agrotóxicos em Alimentos. Cad Saúde Pública 2021; 37:e00116219.

2. Paumgartten FJR. On the health risks of "hidden poisons on our table", good agricultural practices, pesticide residues in food, and dietary exposure assessments. Cad Saúde Pública 2021; 37:e00062221.

3. Carneiro FF, Rigotto RM, Augusto LGS, Friedrich K, Búrigo AC, editors. Dossiê ABRASCO: um alerta sobre os impactos dos agrotóxicos na saúde. Rio de Janeiro: Escola Politécnica de Saúde Joaquim Venâncio, Fundação Oswaldo Cruz/Expressão Popular; 2015.

4. Vasconcelos FD. Uma visão crítica do uso de padrões de exposição na vigilância da saúde no trabalho. Cad Saúde Pública 1995; 11:588-99.

5. Holmberg B, Winell M. Occupational health standards: an international comparation. Scand J Work Environ Health 1977; 3:1-15.

6. Castleman BI, Ziem GE. Corporate influence on threshold limit values. Am J Ind Med 1988; 13:531-59.

7. Ito N, Hagiwara A, Tamano S, Futacuchi M, Imaida K, Shirai T. Effects of pesticide mixtures at the acceptable daily intake levels on rat carcinogenesis. Food Chem Toxicol 1996; 34:1091-6.

8. Robin MM. Our daily poison: from pesticides to packaging, how chemicals have contaminated the food chain and are making us sick. New York: The New Press; 2014.

9. Bombardi LM. Geografia do uso de agrotóxicos no Brasil e conexões com a União Europeia. São Paulo: Faculdade de Filosofia, Letras e Ciências Humanas, Universidade de São Paulo; 2017.

10. Welshons WV, Nagel SC, vom Saal FS. Large effects from small exposures. III. Endocrine mechanisms mediating effects of bisphenol A at levels of human exposure. Endocrinology 2006; 147(6 Suppl):S56-69.

11. Metzdorff SB, Dalgaard M, Christiansen S, Axelstad M, Hass U, Kiersgaard MK, et al. Dysgenesis and histological changes of genitals and perturbations of gene expression in male rats after in utero exposure to antiandrogen mixtures. Toxicol Sci 2007; 98:87-98.

12. Andreollo NA, Santos EF, Araújo MR, Lopes LR. Idade dos ratos versus idade humana: qual é a relação? ABCD Arq Bras Cir Dig 2012; 25:49-51.

13. Séralini GE, Clair E, Mesnage R, Gress S, Defarge N, Malatesta M, et al. Republished study: long-term toxicity of a Roundup herbicide and a Roundup-tolerant genetically modified maize. Environ Sci Eur 2014; 26:14.

Submitted on 22/Apr/2021

Approved on 29/Apr/2021 